\title{
Reflections on the Republication of Mark von Hagen's Essay
}

\author{
Zenon E. Kohut
}

University of Alberta

I

n this issue, East/West: Journal of Ukrainian Studies is republishing the "Introduction" by Mark von Hagen to a special issue of the Harriman Review devoted to the Russian-Ukrainian encounter since the end of the Soviet Union. This brief essay is perhaps von Hagen's best account on how to approach research on the history of Ukrainian and Russian identities in the context of the transformation of the Soviet Union into a system of successor states. The article was published as part of the proceedings of the final conference of a four-part series that was convened alternately in Cologne and New York City. As an organizer and participant of this project, I would like to provide some context that would elucidate the project's origins and goals as well as von Hagen's crucial role in its inception and execution.

In the wake of Ukraine's declaration of independence, UkrainianRussian relations became an issue of critical importance in the work of the Canadian Institute of Ukrainian Studies (CIUS) at the University of Alberta. In 1992 CIUS Press published a collection of essays entitled Ukraine and Russia in Their Historical Encounter (Potichnyj et al.). This collection included updated versions of papers presented at a historical conference on Ukrainian-Russian relations held at McMaster University in October 1981. The articles in the collection sparked a very lively discussion on the pages of the interdisciplinary journal Canadian Slavonic Papers (vol. XXXV, nos. 1-2 and. vol. XXXV, nos. 3-4, September-December 1993).

While these efforts were useful, they were clearly insufficient. Frank Sysyn and I came to the conclusion that a new major international initiative was necessary to reassess the Ukrainian-Russian encounter from the premodern period to current developments. We received most enthusiastic support from my close friend Mark von Hagen, then at Columbia University, and Andreas Kappeler, then at the University of Cologne. Thus the "Peoples, Nations, Identities: The Russian-Ukrainian Encounter" Project was born. We deliberately chose the "Encounter" subtitle to connect with the 1981 conference and the 1992 book. Initially the Peoples, Nations, Identities Project was conceived as a joint Canadian, American, German international three-year project that would draw together more than 80 specialists in Ukrainian and Russian studies, who would address specific questions in 
Ukrainian-Russian relations in a series of seminars. The objective of this project was to explain and interpret the nature of the relationship between the Ukrainian and Russian nations and identities from a historical perspective. The specialists participating in the seminar series were expected to bring new methodologies and innovative approaches to the variety of disciplines and subjects that were to be covered in a series of workshops.

These seminars and workshops, whose venues would alternate between New York, Cologne, and Toronto/Edmonton, would adhere to a loosely chronological framework, commencing with the pre-modern period and concluding with current developments. Von Hagen, Kappeler, and I drafted a project funding proposal. Without doubt von Hagen wrote a major part of the proposal. The proposal was submitted to the Social Sciences and Humanities Research Council (SSHRC) in Canada, the National Endowment for the Humanities (NEH) in the U.S., and the Humboldt Foundation of Germany. SSHRC rejected the proposal while NEH and Humboldt accepted it. Thus the project was reconstructed to have the seminars alternate between New York and Cologne. The first and third conferences were held at the University of Cologne (23-25 June 1994 and 15-17 June 1995), while the second and fourth were at Columbia University (13-15 November 1994 and 21-23 September 1995). There was an additional institutional participant for the fourth workshop-the Center for Russian and East European Studies at Yale University, with funding provided by the Chopivsky Family Foundation. CIUS Press published selected papers from the first three meetings (Kappeler); Columbia's Harriman Institute issued the proceedings of the fourth conference for which von Hagen wrote this "Introduction" (Peoples, Nations, Identities).

Von Hagen's enthusiasm and dedication were crucial for the completion of this project. He was instrumental in its conception and execution. Von Hagen helped shape the project proposal and worked tirelessly to organize the workshops, particularly the ones scheduled in New York. He also had a profound impact on the project's intellectual and methodological focus, and it is my belief that the project also had a similar effect on his thinking. It is at this time that von Hagen published his now classic article "Does Ukraine Have a History?". Much of his later work dealt with Ukraine, often through examinations of empires and nations. Indeed, von Hagen became a prominent historian of Ukraine and organizer of Ukrainian studies. His untimely passing was a profound loss to me personally, the CIUS, and the academic community. It is my hope that the republication of von Hagen's "Introduction" not only will remind the academic public of his goals and vision but will also serve as a tribute of a remarkable life. 
Works Cited

Kappeler, Andreas, et al., editors. Culture, Nation, and Identity: The Ukrainian-Russian Encounter, 1600-1945. CIUS P, 2003.

Peoples, Nations, Identities: The Russian-Ukrainian Encounter. Special Issue of The Harriman Review, vol. 9, nos. 1-2, Spring 1996.

Potichnyj, Peter J. et al. Ukraine and Russia in Their Historical Encounter. CIUS P, 1992. von Hagen, Mark. "Does Ukraine Have a History?" Slavic Review, vol. 54, no. 3, 1995, pp. 658-73. 